\title{
限界塑性変位量を用いた既設グラウンドアンカー工の評価基準の提案
}

\section{Proposal of criteria to the existing ground anchor that uses the amount of the limit plasticity displacement}

\author{
瀬崎＼cjkstart茂 ${ }^{\text {a)* } ・ \text { 小滰辰人 }}{ }^{\text {a) } ・ \text { 池田靖彦 }}{ }^{\text {a) }} \cdot$ 浜野浩幹 $^{\text {b) }}$ \\ Shigeru SESAKI, Yoshito KOTAKI, Yasuhiko IKEDA and Hiroki HAMANO
}

\begin{abstract}
In this research, pulling test of anchor piles had been carried out in fields and the indoor. By analyzing test results, effective length and limit plastic displacement of piles are obtained. By using these results, evaluation method for degree of soundness of piles is proposed by examining limit plastic displacement rate for effective length of piles. In addition, it is pointed out that anchor forces don't transmit effectively to the anchorage zone if free length of piles is so long, and it is important that pile test must be carried out within a design load because significant plastic displacements is caused for more loads.
\end{abstract}

Key words : length of effective anchor, pull-out form of anchor body, critical plastic deformation rate, lift off test

\section{和文要旨}

本研究では現場および室内での引抜き試験を行い，その結果を解析してアンカー体の有効長や限界塑性変位量を求めた。これら を用いてアンカー体の有効長に対する限界塑性変位量率を求め, アンカー体の健全度評価手法を提案した。さらにアンカー体の塑 性変位を助長しないように試験荷重は設計荷重以内で実施することの必要性や，自由長が長い場合にはアンカーカが定着部に有効 に伝達していない等の問題点を指摘した。

キーワード：有効アンカー体長，アンカー体の引抜き形態，限界塑性変位量率，リフトオフ試験

\section{1. はじめに}

既設グラウンドアンカー工（以下アンカー工もしくは アンカーとする）のメンテナンスにおいて，アンカー体 の健全度に関する評価は不可欠である。その方法として リフトオフ試験および緊張力解除後の多サイクル試験等 があるが，これには以下に示す問題を持っている。(1)現 在機能しているアンカーを破壊してしまう可能性もある ので，試験荷重の設定など試験の計画には十分な注意が 必要とされている1)。(2)古い時期に施工されたアンカー では設計あるいは施工管理資料がない場合が多く，その 健全度を適正に評価することは困難である。(3)設計施工 資料がある場合でも，アンカー体の供用可能期間等の評 価を行うにはその管理基準が必要である。(4)メンテナン ス費高騰に対処するためにも，評価手法としてはできる だけ安価（簡便）なものが望まれる。

本研究ではこれらの問題に対し室内および現場で行っ た引抜き試験結果を検討し，設計荷重に対する概略的な 健全度と供用可能期間に関わるアンカー体の劣化度によ る評価方法を提案した。具体的には，前者はリフトオフ 荷重から設計荷重にかけての 1 サイクル試験における荷 重一塑性変位量曲線の形態による評価，後者はアンカー 体の支持機構を考慮した限界塑性変位量による評価であ る。検討対象は一般に普及している引張型および圧縮型 アンカーとした。

* 連絡著者/corresponding author

a ）株式会社日西テクノプラン

Nissei Techno Plan Co L Ltd

广 $690-0011$ 島根県松江市東津田町1329-1

1329-1, higashitsuda, matsue, shimane, japan

b ) 松江工業高等専門学校

Matsue College of Technology

\section{2.アアンカー体の模型引抜き実験}

アンカー体長と引抜き荷重および限界塑性変位量の関 係を，セメントミルクで造成した模型地盤での引抜き試 験により検証する。

\section{1 実験仕様}

実験は図－1のように鋼製スパイラルダクト管（ $\phi 50$ $\mathrm{cm}$, 管厚 $8 \mathrm{~mm}$, 高さ $1.5 \mathrm{~m})$ にアンカー体 $(\phi 13 \mathrm{~mm}$, グラウト強度 $q_{\mathrm{u}}=32.3 \mathrm{MPa}$ ）を造成し，引張型および圧 縮型についてそれぞれ 3 種類の模型地盤 $\left(q_{\mathrm{u}}=2.0,2.7\right.$, $3.5 \mathrm{MPa}$ ）を用いて各15本ずつ引抜き試験を行った。ア ンカー体長は $10 \mathrm{~cm} \sim 150 \mathrm{~cm}$ (10cmピッチ) とし，テン ドンとして総ネジ鉄筋 $(\phi 8 \mathrm{~mm}, \mathrm{ss} 400$, 引張り強さ $14.8 \mathrm{kN} /$ 本) を使用した。

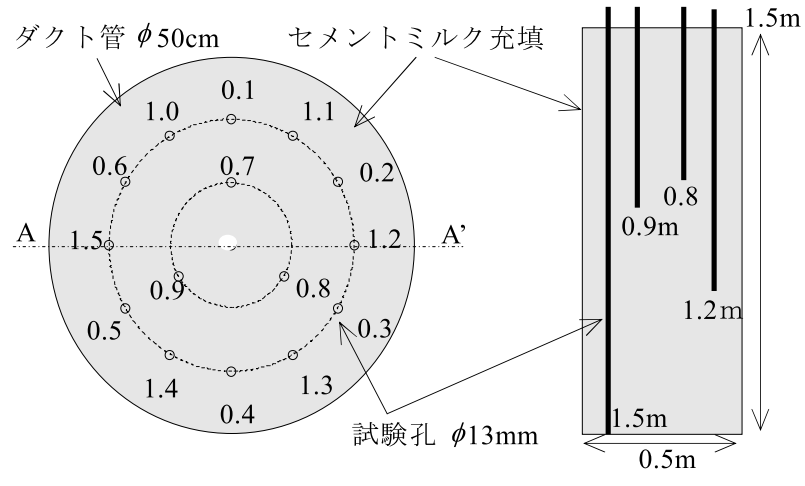

(平面配置図. 数字はアンカー体長 $\mathrm{m}$ )

( $\mathrm{A}-\mathrm{A}^{\prime}$ 断面)

図一 1 スパイラルダクト管内の引抜き試験孔配置図

Fig. 1 Arrangement chart of the pull-out test's hole in spiral-duct tube 
各アンカー体の間隔は隣接するアンカー体の影響を避 けるため $7.5 \mathrm{~cm}$ 以上（アンカー体半径の10倍以上）離し, 深さ方向でも深度別に 1 つ置きに配置した。アンカー体 間隔の根拠は, 後述する第 3 章の現場実験 (図-11 (b)) においてアンカー体 $(\phi 11.5 \mathrm{~cm})$ から伝わる応力範囲 $(\phi 50 \mathrm{~cm})$ がアンカー体径の 4.3 倍程度であることから， アンカー体半径の 10 倍以上離せば，相互干渉を避けるこ とができると判断した。

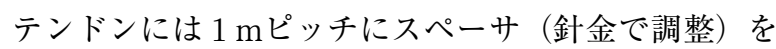
取り付けた（図-2）。圧縮型の拘束具は $\phi 8 \mathrm{~mm}$ 用ナッ 卜（最大 $\phi 11.5 \mathrm{~mm} ）$ で構築し, 拘束具以外はビニール テープでシースした。

模型地盤はセメントミルクとベントナイトで強度調整 した。アンカー体のグラウトはアンカー体が鉛直（引張 り側が天端）となる状態で行い，天端のブリージングに 対しては同質のグラウト材で整形した。

アンカー孔は模型地盤をグラウトする前に $\phi 13 \mathrm{~mm}$ の 丸鋼を所定の位置にセットしておき，グラウト 1 日後に これを引抜くことで構築した。アンカー体のグラウトは $\phi 10 \mathrm{~mm}$ (内径 $8.8 \mathrm{~mm}$ ) のステンレスパイプを用いて孔 底よりおこない，グラウト材のオーバーフローを確認後， テンドンを挿入する方法とした。

試験順序はアンカー体長の短いものから実施し, アン カー体の引張り側の変位を拘束しないよう，枅形の鋼製 ラムチェア（辺長 $7.5 \mathrm{~cm} \times 7.5 \mathrm{~cm}$, 高さ $5 \mathrm{~cm}$, 内壁寸 法 $5.5 \mathrm{~cm} \times 5.5 \mathrm{~cm}$ ，鉄板厚 $1 \sim 2 \mathrm{~cm} ）$ とセンターホー ル型ジャッキを用いた（図ー3）。試験荷重は引抜ける

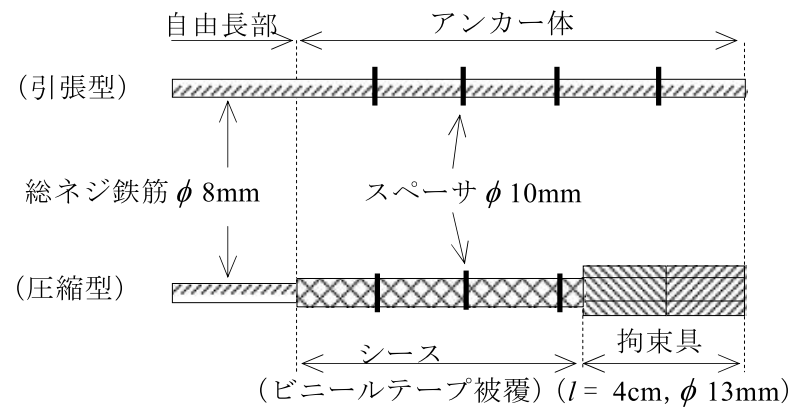

図ー2 引張り試験用テンドン構造図

Fig. 2 Tendon's structural chart for pull-out test

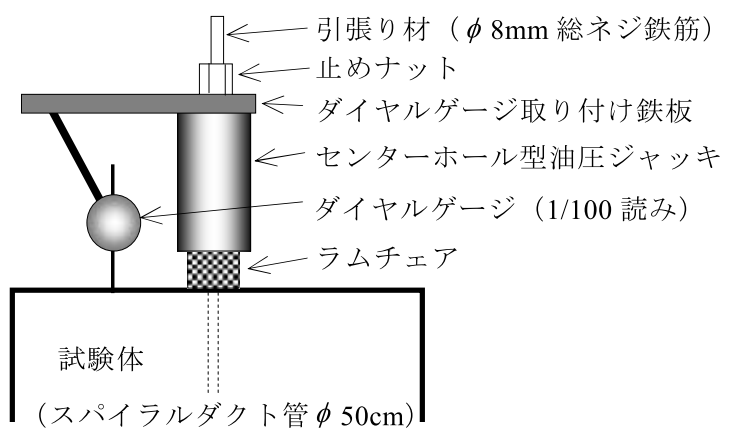

図一３引抜き試験装置組み立て図

Fig. 3 Assembly figure of test fixture for pull-out test
までテンドン引張り強さの $1 / 10$ 刻み，すなわち $1.4 \mathrm{kN}$ 刻みで増加させ，引抜け量はダイヤルゲージ（1/100読 み）で測定した。

\section{2 実験結果}

図-4は引張り試験時の荷重とテンドンの伸び変位量 を実測したものである。試験時の荷重は引張り材の引張 り強さ以下であり，したがって同図に示す変位量は荷重 段階毎のテンドンの弾性変位とアンカー体の引抜け変位 を主とする塑性変位を合わせたものとなる。よって理論 伸び量をテンドンの自由長に弾性係数を乗じて求め, 全 変位量からこれを引いたものを塑性変位量とした。この 塑性変位量を基に，アンカー体の降伏荷重と引抜き荷重 の判定基準を以下のように設定した。

○降伏荷重：塑性変位量曲線において引抜き前に直線 状の増加（図 - 4 の点線で示す補助線）から漸増し 始める屈曲点がみられる。これを引抜け前の降伏点 とみなし，この時の荷重を降伏荷重とする。またこ の時のアンカー体長を有効長とする。

○引抜き荷重：アンカー体が引抜ける直前の，塑性変 位が急増し始める時の荷重とする。

\subsection{1 アンカー体長と降伏荷重および有効長}

実験結果は表 - 1 のようであり, 模型地盤の強度を 2.7 〜3.5MPaに設定して行ったが，全体としてほぼ一定し ている。よって全体的傾向を把握するため, 各地盤強度 における降伏荷重の平均值を用いてアンカー体長との関 係を検討する。結果を図ー 5 に示す。

同図によれば引張型および圧縮型ともに，アンカー体 長 $30 \mathrm{~cm}$ までは長さに応じて降伏荷重が増大するが，そ れ以上ではほとんど増大しない。従って，本実験でのア ンカー体の有効長（以下有効長とする）は引張型および 圧縮型ともに $30 \mathrm{~cm}$ 程度と判定される。

\subsection{2 アンカー体長と引抜き荷重}

実験結果は表-2のようであり，降伏荷重（表-1） の場合と同様に模型地盤の強度2.7〜3.5MPaに対して 引抜け荷重はほぼ一定している。よって全体的傾向を把 握するため, 各地盤強度における引抜き荷重の平均值を 用いてアンカー体長との関係を検討する。結果を図 - 6

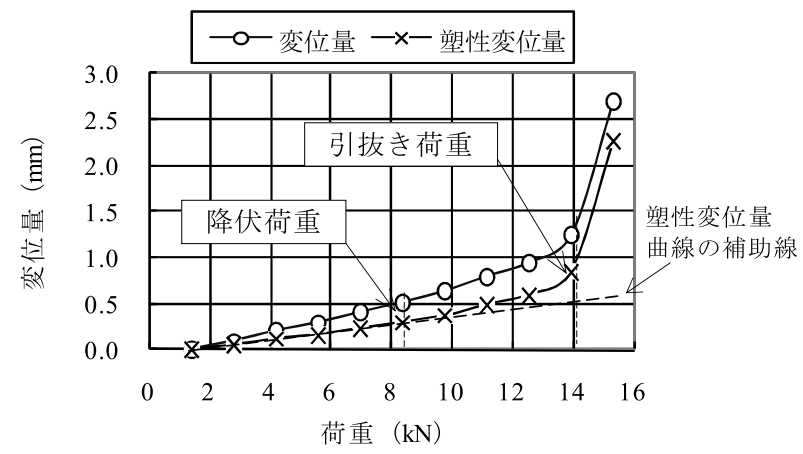

図一 4 荷重一変位量曲線による限界塑性変位量の判定基準

Fig. 4 Judging standard of critical plastic deformation's amount by plasticity deformation amount curve 
表一 1 模型地盤の強度別降伏荷重

Table. 1 Yield load of each strength of the model anchorage material

\begin{tabular}{|c|c|c|c|c|c|c|c|c|}
\hline \multirow{2}{*}{$\begin{array}{c}\text { アンカー } \\
\text { 体長 } \\
(\mathrm{cm})\end{array}$} & \multicolumn{3}{|c|}{$\begin{array}{c}\text { 引張型：被定着材強度 } \\
\text { 別引拢き荷重 }(\mathrm{kN})\end{array}$} & \multirow[t]{2}{*}{ 平均 } & \multicolumn{3}{|c|}{$\begin{array}{c}\text { 圧縮型：被定着材強度 } \\
\text { 別引抜き荷重 }(\mathrm{kN})\end{array}$} & \multirow[t]{2}{*}{ 平均 } \\
\hline & $2.0 \mathrm{MPa}$ & $2.7 \mathrm{MPa}$ & $3.5 \mathrm{MPa}$ & & $2.0 \mathrm{MPa}$ & $2.7 \mathrm{MPa}$ & $3.5 \mathrm{MPa}$ & \\
\hline 10 & \begin{tabular}{|l|}
8.30 \\
\end{tabular} & 9.70 & \begin{tabular}{|l|}
7.10 \\
\end{tabular} & 8.37 & \begin{tabular}{|l|}
7.00 \\
\end{tabular} & \begin{tabular}{|l|}
9.70 \\
\end{tabular} & $\begin{array}{l}7.00 \\
\end{array}$ & 7.90 \\
\hline 20 & 8.30 & 11.10 & 11.10 & 10.17 & 4.20 & 9.70 & 4.20 & 6.03 \\
\hline 30 & 7.00 & 11.10 & 11.10 & 9.73 & 8.30 & 7.00 & 7.00 & 7.43 \\
\hline 40 & 9.70 & 11.10 & 11.10 & 10.63 & 4.20 & 8.30 & 8.30 & 6.93 \\
\hline 50 & 9.70 & 12.50 & 9.70 & 10.63 & 5.60 & 8.30 & 7.00 & 6.97 \\
\hline 60 & 9.70 & 12.50 & 7.00 & 9.73 & 5.60 & 7.00 & 8.30 & 6.97 \\
\hline 70 & 9.70 & 9.70 & 12.50 & 10.63 & 8.30 & 7.00 & 9.70 & 8.33 \\
\hline 80 & 11.10 & 8.30 & 8.30 & 9.23 & 5.60 & 7.00 & 5.60 & 6.07 \\
\hline 90 & 11.10 & 11.10 & 11.10 & 11.10 & 4.20 & 7.00 & 8.30 & 6.50 \\
\hline 100 & 9.70 & 11.10 & 12.50 & 11.10 & 7.00 & 6.00 & 7.00 & 6.67 \\
\hline 110 & 9.70 & 11.10 & 12.50 & 11.10 & 4.20 & 4.20 & 5.60 & 4.67 \\
\hline 120 & 9.70 & 9.70 & 12.50 & 10.63 & 8.30 & 7.00 & 5.60 & 6.97 \\
\hline 130 & 11.10 & 12.50 & 11.10 & 11.57 & 7.00 & 7.00 & 5.60 & 6.53 \\
\hline 140 & 9.70 & 12.50 & 11.10 & 11.10 & 7.00 & 7.00 & 7.00 & 7.00 \\
\hline 150 & 11.10 & 11.10 & 12.50 & 11.57 & 5.60 & 5.60 & 7.00 & 6.07 \\
\hline
\end{tabular}

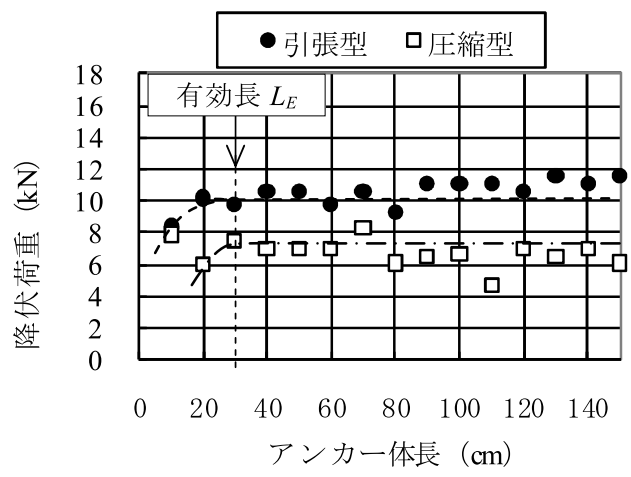

図－5 アンカー体長と降伏荷重 (模型地盤 $q_{u}=2.0 \sim 3.5 \mathrm{MPa}$ の平均値)

Fig. 5 Length of anchor body and yield load

(Meanvalue of model anchorage Material $q_{u}=2.0$ 3. $5 \mathrm{MPa}$ )

\section{表一 2 模型地盤の強度別引抜き荷重}

Table. 2 Pull-out load of each strength of model anchorage material

\begin{tabular}{|c|c|c|c|c|c|c|c|c|}
\hline \multirow{2}{*}{$\begin{array}{c}\text { アンカー } \\
\text { 体長 } \\
(\mathrm{cm})\end{array}$} & \multicolumn{3}{|c|}{$\begin{array}{c}\text { 引張型：被定着材強度 } \\
\text { 別降伏荷重 }(\mathrm{kN})\end{array}$} & \multirow[t]{2}{*}{ 平均 } & \multicolumn{3}{|c|}{$\begin{array}{c}\text { 圧縮型: 被定着材強度 } \\
\text { 別降伏荷重 }(\mathrm{kN})\end{array}$} & \multirow[t]{2}{*}{ 平均 } \\
\hline & $2.0 \mathrm{MPa}$ & $2.7 \mathrm{MPa}$ & $3.5 \mathrm{MPa}$ & & $2.0 \mathrm{MPa}$ & $2.7 \mathrm{MPa}$ & $3.5 \mathrm{MPa}$ & \\
\hline 10 & 11.10 & \begin{tabular}{|l|}
13.90 \\
\end{tabular} & 9.70 & 11.57 & 8.30 & 11.10 & 13.90 & 11.10 \\
\hline 20 & 12.50 & 13.90 & 13.90 & 13.43 & 4.20 & 9.70 & 4.20 & 6.03 \\
\hline 30 & 15.30 & 13.90 & 15.30 & 14.83 & 9.70 & 7.00 & 7.00 & 7.90 \\
\hline 40 & 16.70 & 13.90 & 15.30 & 15.30 & 4.20 & 8.30 & 8.30 & 6.93 \\
\hline 50 & 15.30 & 15.30 & 13.90 & 14.83 & 9.70 & 9.70 & 9.70 & 9.70 \\
\hline 60 & 15.30 & 15.30 & 13.90 & 14.83 & 7.00 & 12.50 & 9.70 & 9.73 \\
\hline 70 & 13.90 & 13.90 & 15.30 & 14.37 & 8.30 & 11.10 & 11.10 & 10.17 \\
\hline 80 & 13.90 & 13.90 & 15.00 & 14.27 & 8.00 & 13.90 & 8.30 & 10.07 \\
\hline 90 & 15.00 & 15.30 & 13.90 & 14.73 & 7.00 & 12.50 & 11.10 & 10.20 \\
\hline 100 & 13.90 & 13.90 & 13.90 & 13.90 & 7.00 & 11.10 & 8.30 & 8.80 \\
\hline 110 & 13.90 & 13.90 & 13.90 & 13.90 & 7.00 & 11.10 & 12.50 & 10.20 \\
\hline 120 & 13.90 & 13.90 & 13.90 & 13.90 & 8.30 & 11.10 & 13.90 & 11.10 \\
\hline 130 & 13.90 & 13.90 & 13.90 & 13.90 & 9.70 & 11.10 & 12.50 & 11.10 \\
\hline 140 & 13.90 & 13.90 & 13.90 & 13.90 & 9.70 & 12.50 & 12.50 & 11.57 \\
\hline 150 & 13.90 & 13.90 & 13.90 & 13.90 & 12.50 & 13.90 & 9.70 & 12.03 \\
\hline
\end{tabular}

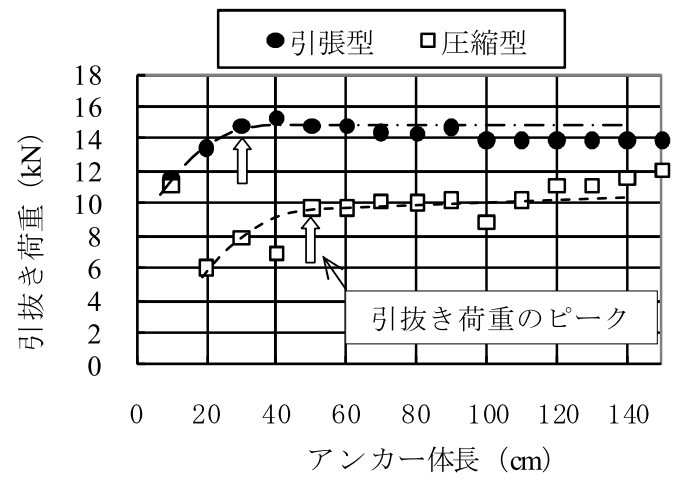

図一６ アンカー体長と引抜き荷重（模型地盤 $q_{u}=2.0 \sim 3.5$ $\mathrm{MPa}$ の平均値)

Fig. 6 Length of anchor body and pull-out load

(Mean value of model anchorage material $q_{u}=2.0$ 3. $5 \mathrm{MPa}$ )

\section{表一 3 模型地盤の強度別アンカー体限界塑性変位量と有効長に対する限界塑性変位量率}

Table. 3 Critical plastic deformation amount and critical plastic deformation rate against effective length by the strength of the model anchorage material

\begin{tabular}{|c|c|c|c|c|c|c|c|c|c|c|c|c|c|c|c|c|c|}
\hline \multirow{3}{*}{$\begin{array}{c}\text { アンカ } \\
\text { 一体長 } \\
(\mathrm{cm})\end{array}$} & \multirow{3}{*}{$\begin{array}{l}\text { 有効 } \\
\text { 長 } \\
(\mathrm{cm})\end{array}$} & \multicolumn{6}{|c|}{ 引張型アンカー体 } & \multirow{3}{*}{ 平均 } & \multirow{3}{*}{$\begin{array}{c}\text { アンカ } \\
\text { 一体長 } \\
(\mathrm{cm})\end{array}$} & \multirow{3}{*}{$\begin{array}{l}\text { 有効 } \\
\text { 長 } \\
(\mathrm{cm})\end{array}$} & \multicolumn{6}{|c|}{ 圧縮型アンカー体 } & \multirow{3}{*}{ 平均 } \\
\hline & & \multicolumn{2}{|c|}{$\begin{array}{c}\text { 模型地盤 } q_{u} \\
=2.0 \mathrm{MPa}\end{array}$} & \multicolumn{2}{|c|}{$\begin{array}{c}\text { 模型地盤 } q_{u} \\
=2.7 \mathrm{MPa} \\
\end{array}$} & \multicolumn{2}{|c|}{$\begin{array}{c}\text { 模型地盤 } q_{u} \\
=3.5 \mathrm{MPa} \\
\end{array}$} & & & & \multicolumn{2}{|c|}{$\begin{array}{c}\text { 模型地盤 } q_{u} \\
=2.0 \mathrm{MPa}\end{array}$} & \multicolumn{2}{|c|}{$\begin{array}{c}\text { 模型地盤 } q_{u} \\
=2.7 \mathrm{MPa}\end{array}$} & \multicolumn{2}{|c|}{$\begin{array}{c}\text { 模型地盤 } q_{u} \\
=3.5 \mathrm{MPa}\end{array}$} & \\
\hline & & $\delta$ & \begin{tabular}{|l|}
$r$ \\
\end{tabular} & $\delta$ & $r$ & $\delta$ & $r$ & & & & $\delta$ & $r$ & $\delta$ & $r$ & $\delta$ & $r$ & \\
\hline 10 & 10 & 50 & $0.50 \%$ & 60 & $0.60 \%$ & 23 & $0.23 \%$ & $0.44 \%$ & 10 & 10 & $\overline{59}$ & $0.59 \%$ & 49 & $0.49 \%$ & 116 & $1.16 \%$ & $0.75 \%$ \\
\hline 20 & 20 & 62 & $0.31 \%$ & 60 & $0.30 \%$ & 124 & $0.62 \%$ & $0.41 \%$ & 20 & 20 & 4 & $0.02 \%$ & 75 & $0.38 \%$ & 38 & $0.19 \%$ & $0.20 \%$ \\
\hline 30 & 30 & 150 & $0.50 \%$ & 54 & $0.18 \%$ & 207 & $0.69 \%$ & $0.46 \%$ & 30 & 30 & 74 & $0.25 \%$ & 99 & $0.33 \%$ & 50 & $0.17 \%$ & $0.25 \%$ \\
\hline 40 & 30 & 297 & $0.99 \%$ & 100 & $0.33 \%$ & 130 & $0.43 \%$ & $0.59 \%$ & 40 & 30 & 17 & $0.06 \%$ & 47 & $0.16 \%$ & 78 & $0.26 \%$ & $0.16 \%$ \\
\hline 50 & 30 & 123 & $0.41 \%$ & 451 & $1.50 \%$ & 149 & $0.50 \%$ & $0.80 \%$ & 50 & 30 & 69 & $0.23 \%$ & 278 & $0.93 \%$ & 70 & $0.23 \%$ & $0.46 \%$ \\
\hline 60 & 30 & 133 & $0.44 \%$ & 151 & $0.50 \%$ & 270 & $0.90 \%$ & $0.62 \%$ & 60 & 30 & 74 & $0.25 \%$ & 83 & $0.28 \%$ & 126 & $0.42 \%$ & $0.31 \%$ \\
\hline 70 & 30 & 76 & $0.25 \%$ & 59 & $0.20 \%$ & 265 & $0.88 \%$ & $0.44 \%$ & 70 & 30 & 67 & $0.22 \%$ & 61 & $0.20 \%$ & 142 & $0.47 \%$ & $0.30 \%$ \\
\hline 80 & 30 & 83 & $0.28 \%$ & 150 & $0.50 \%$ & 528 & $1.76 \%$ & $0.85 \%$ & 80 & 30 & 31 & $0.10 \%$ & 168 & $0.56 \%$ & 162 & $0.54 \%$ & $0.40 \%$ \\
\hline 90 & 30 & 108 & $0.36 \%$ & 236 & $0.79 \%$ & 128 & $0.43 \%$ & $0.52 \%$ & 90 & 30 & 31 & $0.10 \%$ & 119 & $0.40 \%$ & 46 & $0.15 \%$ & $0.22 \%$ \\
\hline 100 & 30 & 131 & $0.44 \%$ & 103 & $0.34 \%$ & 133 & $0.44 \%$ & $0.41 \%$ & 100 & 30 & 50 & $0.17 \%$ & 86 & $0.29 \%$ & 191 & $0.64 \%$ & $0.36 \%$ \\
\hline 110 & 30 & 85 & $0.28 \%$ & 50 & $0.17 \%$ & 125 & $0.42 \%$ & $0.29 \%$ & 110 & 30 & 97 & $0.32 \%$ & 88 & $0.29 \%$ & 168 & $0.56 \%$ & $0.39 \%$ \\
\hline 120 & 30 & 76 & $0.25 \%$ & 113 & $0.38 \%$ & 104 & $0.35 \%$ & $0.33 \%$ & 120 & 30 & 143 & $0.48 \%$ & 56 & $0.19 \%$ & 228 & $0.76 \%$ & $0.47 \%$ \\
\hline 130 & 30 & 127 & $0.42 \%$ & 74 & $0.25 \%$ & 143 & $0.48 \%$ & $0.38 \%$ & 130 & 30 & 233 & $0.78 \%$ & 71 & $0.24 \%$ & 161 & $0.54 \%$ & $0.52 \%$ \\
\hline 140 & 30 & 98 & $0.33 \%$ & 187 & $0.62 \%$ & 125 & $0.42 \%$ & $0.46 \%$ & 140 & 30 & 111 & $0.37 \%$ & 160 & $0.53 \%$ & 124 & $0.41 \%$ & $0.44 \%$ \\
\hline 150 & 30 & 86 & $0.29 \%$ & 83 & $0.28 \%$ & 253 & $0.84 \%$ & $0.47 \%$ & 150 & 30 & 225 & $0.75 \%$ & 243 & $0.81 \%$ & 94 & $0.31 \%$ & $0.62 \%$ \\
\hline 平均 & & 112 & $0.40 \%$ & 129 & $0.46 \%$ & 180 & $0.63 \%$ & $0.50 \%$ & 平均 & & 86 & $0.31 \%$ & 112 & $0.40 \%$ & 120 & $0.45 \%$ & $0.39 \%$ \\
\hline
\end{tabular}

$(\delta$ : 限界塑性変位量 $1 / 100 \mathrm{~mm}, r$ : 限界塑性変位量率) 
に示す。同図から，アンカー体の引抜き荷重は，引張型 では長さ $30 \mathrm{~cm}$ 以上で概ね $14 \mathrm{kN}$ とほぼ同じ值を示す。圧 縮型ではアンカー体長 $50 \mathrm{~cm}$ 以上で $10 \mathrm{kN}$ とほぼ一定であ るが，その後もやや引抜き荷重が増大する傾向にある。 これは圧縮型の場合，拘束具（荷重作用点）の埋設深度 が深くなるほど周辺地盤の拘束度が高まることが影響す るものと考えられる。また引張型に比べ引抜け荷重が小 さく，同様の傾向が現場実験でもみられることから，こ れについては第 3 章 2 節 1 項で考察する。

\subsection{3 アンカー体引抜き時の限界塑性変位量と有効 長に対する限界塑性変位量率}

表- 2 に示した模型地盤の強度別引抜き荷重時におけ る限界塑性変位量および限界塑性変位量率を表 - 3 に示 す。ここに，アンカー体の有効長 $L_{E} に$ 対する限界塑性変 位量 $\delta$ を，限界塑性変位量率 $r\left(=\delta / L_{E}\right)$ とする。なお有 効長は前項での実験結果から引張型および圧縮型とも最 大 $30 \mathrm{~cm}$ とする（図－5）。

表 -3 より, 模型地盤の強度每の限界塑性変位量率に 有意な差異は認められなかったので，平均值を用いてア ンカー体長との関係を検討する。結果を図ー 7 に示す。

同図より, 引張型では全体にばらつきが大きいものの, 有効長内の限界塑性変位量率はおよそ $0.45 \%$ である。圧 縮型ではアンカー体長が長くなるほど増大する傾向があ

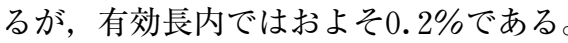

\section{3. アンカー現場引抜き試験}

現場での引抜き試験において，アンカー体周辺地盤の 応力状態を測定することで，その支持機構と有効長およ び塑性変形の特徴について検証する。

\section{1 実験仕様}

試験孔および観測孔の配置を図ー8に示す。アンカー 孔径は $115 \mathrm{~mm}$ とした。テンドンはPC異形棒鋼 $\phi 36 （ 5$ $\mathrm{m} /$ 本，引張り荷重 $1098 \mathrm{kN}$ ）を使用し，スペーサを $1 \mathrm{~m}$ ピッチで取り付けた。圧縮型アンカー体の拘束具は $\phi 36$

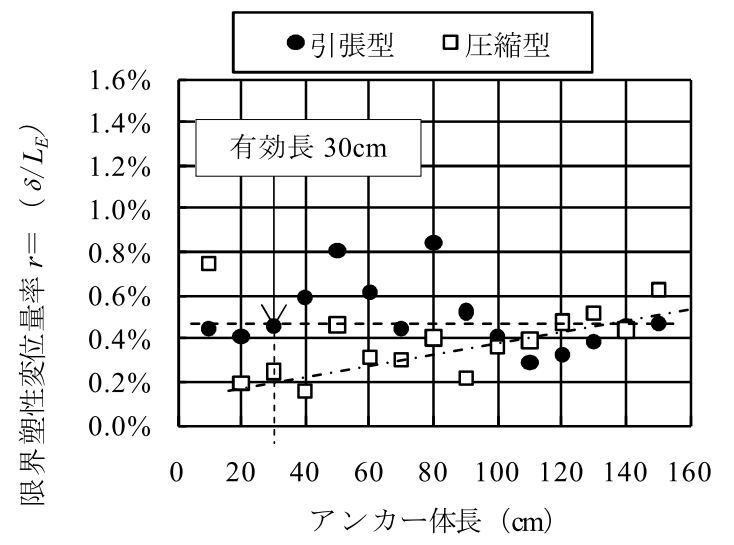

図－７アンカー体長と限界塑性変位量率 (模型地盤 $q_{u}=2.0 \sim 3.5 \mathrm{MPa}$ の平均値)

Fig. 7 Length of anchor body and critical plastic deformation rate (Mean value of model anchorage material $\left.q_{u}=2.0-3.5 \mathrm{MPa}\right)$ $\mathrm{mm}$ 用ナット 2 個の間に，鋼製プレート $(\phi 90 \mathrm{~mm}$ ，厚 さ $20 \mathrm{~mm}$ ）を挟む構造とし，拘束具以外のテンドンはビ ニールテープでシースした（図－9）。

アンカー体から模型地盤に伝わる主応力は歪観測孔 (No.1〜 3) と各試験体 (テンドン) に取り付けた歪ゲー ジにより測定した。歪ゲージは深度 $0.75 \mathrm{~m}$ 地点から $50 \mathrm{~cm}$ ピッチに10点取り付けた。試験体に取り付ける歪ゲージ はアルミ板に貼り付けた状態で所定の位置に固定した。 歪観測孔では塩ビ管（VP-40）を利用し，これに歪ゲー ジを取り付けた。塩ビ管にはスリット加工を施し, 歪ゲー ジ間を伝わるノイズを抑制するようにした。

アンカー体のグラウト $\left(q_{\mathrm{u}}=32.3 \mathrm{MPa}\right)$ はテンドンを 挿入後，あらかじめこれに取り付けておいたホースで孔 底より行ない，完了後ホースは引き抜いた。歪観測孔で は塩ビ管の内外に定着地盤と同程度の強度のセメントミ ルク（ $q_{\mathrm{u}}=3.0 \mathrm{MPa} ）$ を孔底よりグラウトホースで充填 を行い，地山と一体化するようにした（セメントミルク の強度はベントナイトと水セメント比で調整)。

試験孔の地質は凝灰岩であり， GL-3.5mまでは“N 值 $=10$ ０”の強風化帯，これ以深は硬い岩芯を残す弱 風化帯 $\left(q_{\mathrm{u}}=3.8 \mathrm{MPa}\right)$ である。通常，アンカー体は自 由長部の土塊にも拘束されるが，移動土塊の薄いルーズ な崩積土層の地すべり等であればその拘束度は低いと考 えられる。よって歪ゲージの設置精度を確保するために も，ここでは引張型の場合，地表より $0.5 \mathrm{~m}$ 以深にアン カー体を設置した。圧縮型アンカー体は荷重作用点とな る拘束具を弱風化帯内に設置した。試験は引張型，圧縮

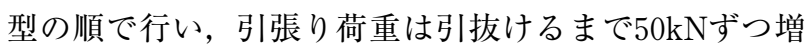
加させる方法とした。

\section{2 実験結果}

\subsection{1 引張型アンカー体の支持機構と有効長}

実験結果は図－10に示すとおり，荷重 $250 \mathrm{kN}$ 以降理論

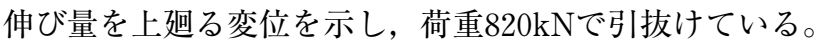
この時のアンカー体側方地盤の応力状態を図 -11 (a)に示

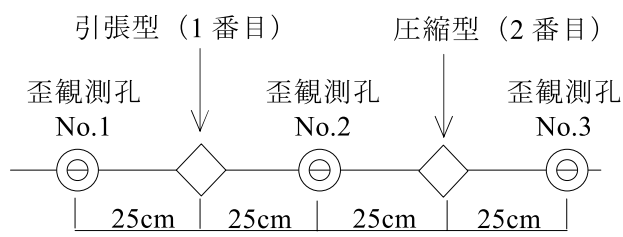

図ー8 試験孔および観測孔の配置と測定順位

Fig. 8 Arrangement and measurement order of examination hole and observation hole

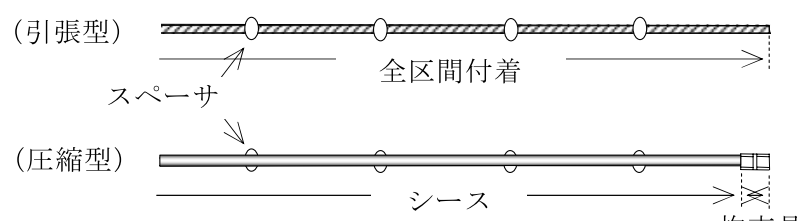

図ー9 テンドン構造図

Fig. 9 Tendon structural chart 
す。同図より，アンカー体沿いには荷重作用点からGL $-2.0 \mathrm{~m}$ 付近まで断続的に圧縮力が働き，荷重 $600 \mathrm{kN}$ 時 にはGL-2.5m付近まで，アンカー体より $25 \mathrm{~cm}$ 離れた 地盤内に不規則な形で大きな引張り力が働いている。ま たこの実験では引抜けと同時に地表部が $\phi 0.5 \mathrm{~m}$ の範囲 で盛り上り，同図(a)に示すコーン状の地盤が抜け上がっ たものとみられる。

一方，図-12は図-11(a)の歪計観測孔（歪）の荷重 段階毎の応力状態を示すものであり，荷重600kNから荷 重 $750 \mathrm{kN}$ に移行した段階で荷重のピーク点がGL-3.75m から $\mathrm{GL}-4.25 \mathrm{~m}$ と深層部に移動している。これはア ンカー体の引抜け状況を示しており，図ー10に示した荷 重250kN以降の塑性変位量の増大を裏付けるものである。 さらに図ー11(a)ではGL-2.5m付近を境にこれ以深では アンカー体から離れた位置に大きな力は作用していない。 したがって $\mathrm{GL}-2.5 \mathrm{~m}$ 付近までが実質的引抜き抵抗区間 であり，この区間を有効長と判定した。

これ以深はアンカー体を中心とした狭い領域で引抜け を生じるため，引抜き抵抗に対する影響も小さいと考え られる。

以上のことから, 引張型はアンカー体が引張り側から 変位することで，周辺地盤等にアンカーカの分散を図る ことができ，これが効果的に行われる区間が有効長をな すものと考えられる。そのため, 特に軟質地盤などでは 後述する圧縮型より大きな引抜き抵抗を発揮できる可能 性が考えられる。

\subsection{2 圧縮型アンカー体の支持機構と有効長}

圧縮型は図ー13に示すように荷重 $500 \mathrm{kN}$ 付近より塑性 変位が増大し，荷重720kNで引抜けている。

アンカー体側方地盤の応力状態は図-11(b)のようであ り, 荷重600kN時には荷重作用点より地表側に約 $3 \mathrm{~m}$, アンカー軸に直交する方向に片側約 $25 \mathrm{~cm}$ の範囲（アン カー体半径の 4.3 倍) で圧縮力が働いている。同図の歪 計観測孔（歪2）に打ける荷重段階毎の応力状態は図14に示すとおりである。引抜ける直前（700kN）におい ても荷重作用点は深度 $4.5 \mathrm{~m} て ゙ 一$ 定しており, 引張型 (図

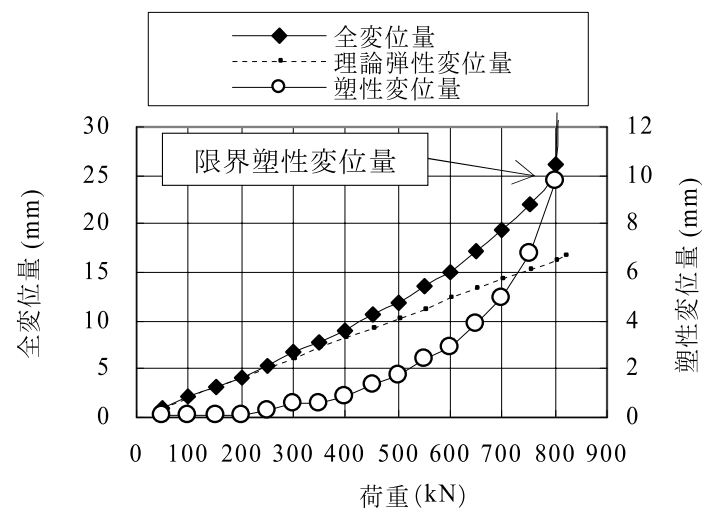

図-10 荷重一変位量曲線（引張型）

Fig. 10 Plasticity deformation amount curve (tension type)
-12）との違いが明瞭である

アンカー体はこの応力状態を保ったまま引抜けに至っ ており，その有効長は図-11(b)に示す圧縮力の分布状況 から約 $3 \mathrm{~m}$ と判定される。引抜け時には爆発的破壊音を 生じたが, 引張型のような地表面の変位は認められな かった。したがって拘束具を中心としたアンカー体およ び周辺地盤内での引抜け破壊であり，主にアンカー体お よび周辺地盤の支圧強度により引抜き抵抗が発揮される ものと考えられる。

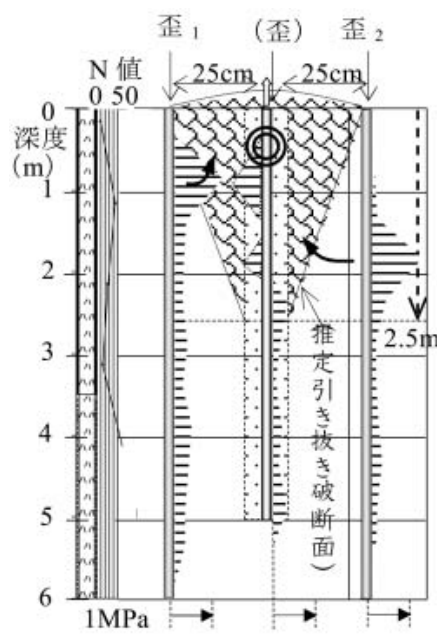

(a) 引張型

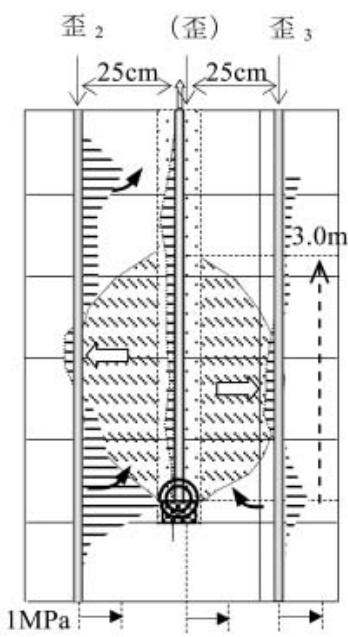

(b) 圧縮型

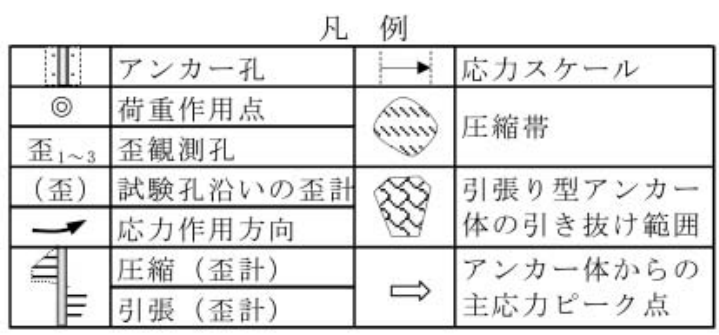

図ー11 アンカー体周辺地盤の応力状態測定図 （荷重600kN時）

Fig. 11 Stress state's-measurement chart of anchorage material around anchor body (At load600kN)
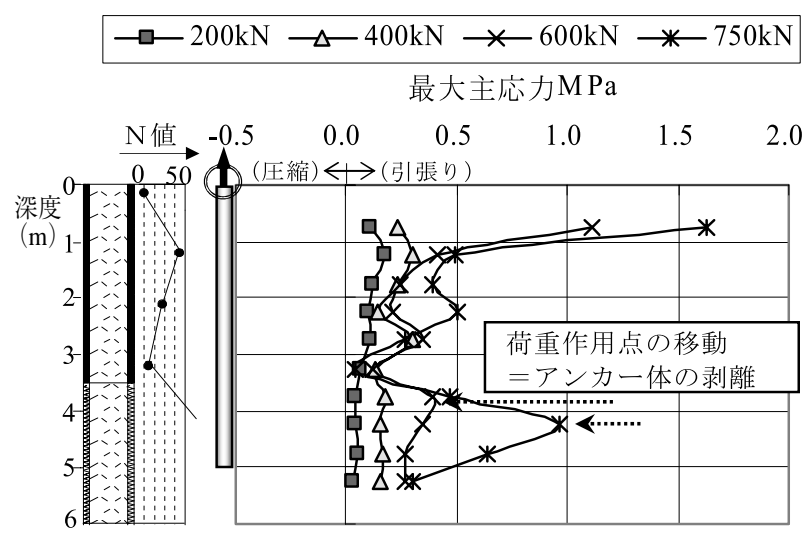

図-12 引張型アンカー体側方地盤内の応力変化図

Fig. 12 Stress change chart of the ground around tension type's anchor body 


\subsection{3 塑性変位量曲線の特徵と限界塑性変位量}

図－10，13に示す各アンカー体の荷重－変位量曲線よ り，引張型および圧縮型ともに塑性変位量が放物線状に 増大し引抜けている。実験で使用したテンドン（PC異 形棒鋼 $\phi 36)$ のリラクセーション幅は $1.5 \%$ 以下（荷重 768. $6 \mathrm{kN}$ で1000時間負荷）である。測定時間が短いこと （1 時間以内）や荷重が小さいこと（50〜800kN）を考 慮し，その影響を無視すれば，大きく増大するまでの塑 性変位量は地盤およびアンカー体自体の塑性変位，放物 線状に増大するのがアンカー体自体の引抜けを示すと推 定される。その引抜き直前に確認された值を限界塑性変 位量とすれば，引張型で $9.8 \mathrm{~mm}$ (荷重 $800 \mathrm{kN}$ 時)，圧縮 型で3.3mm（荷重700kN時）となる。

\subsection{4 有効長に対する限界塑性変位量率}

上記試験結果より，アンカー体の限界塑性変位量率 $\mathrm{r}$ $\left(=\delta / L_{E}\right)$ は引張型で $0.39 \%$ （限界塑性変位量 $0.98 \mathrm{~cm}$, 有効長 $250 \mathrm{~cm}$ ), 圧縮型で $0.11 \%$ (限界塑性変位量 $0.33 \mathrm{~cm}$, 有効長 $300 \mathrm{~cm}$ ）となる。引張型の方が大きい值を示して おり，同アンカー体が引張り側から徐々に剥離すること と関連するものである。

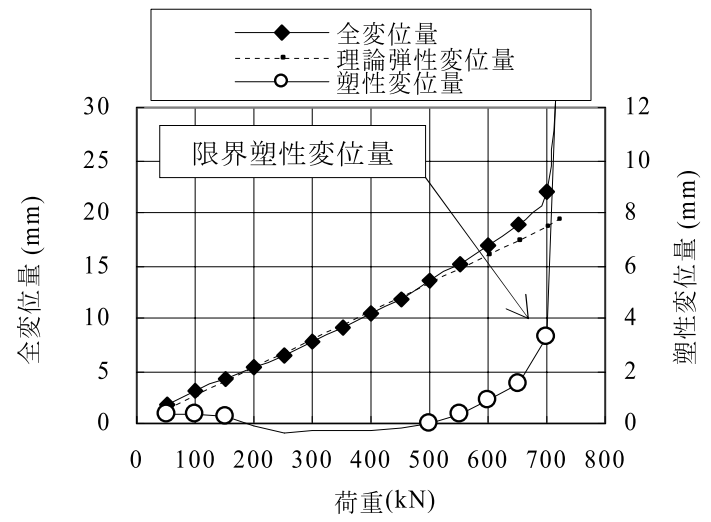

図-13 荷重一変位量曲線（圧縮型）

Fig. 13 Load-displacement amount curve (compression-concentrating type)
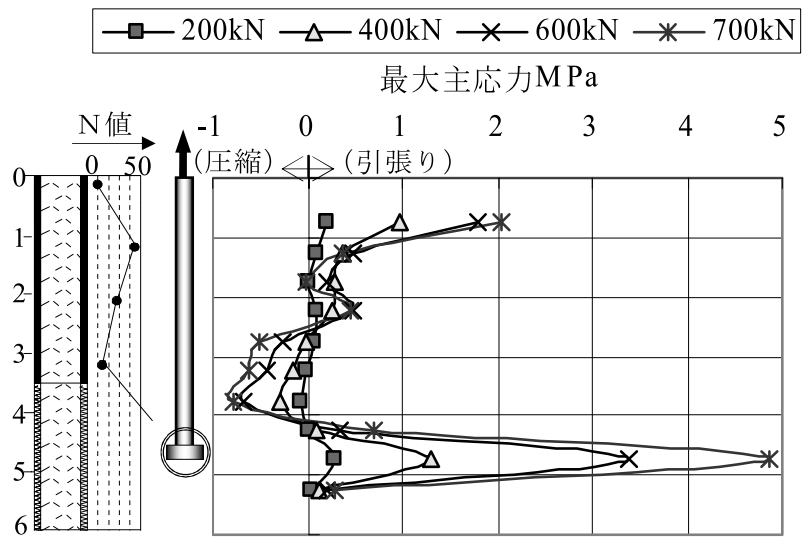

図－14 圧縮型アンカー体側方地盤内の応力変化図

Fig. 14 Stress change chart of the ground around compression-concentrating type's anchor body

\section{4. 限界塑性変位量率のアンカー体健全度評価指標とし ての適応性}

表－4は第2，3章に示した引抜き試験によるアンカー 体の有効長とアンカー体径の関係を示すものであり，有 効長とアンカー体径の比（以下有効長比とする）は22〜 26倍とほぼ一定している。

これが妥当なものとして，現場で行った引張型アン カー体の限界塑性変位量率を求めれば表－5のようにな る。ただし，有効長比は表 -4 に示す引張型の現場実験 結果（有効長比22）を用いた。また有効長は，アンカー 体径に上記有効長比を乗じたものを最大有効長とし，こ れと試験時のアンカー体長を比較し，短い方を採用した。

表 -5 に示す限界塑性変位量率 $r$ と定着地盤の強度の 関係は図－15のように示される。同図より，定着地盤の 強度が $1 \mathrm{MPa}$ 程度以下では 1 〜 $2 \%$ と大きが， $2 \mathrm{MPa}$ より固い地盤では約 $0.5 \%$ と一定值を示す傾向にある。

一般に地すべり地での定着地盤は, その強度が $10 \mathrm{MPa}$ 以下を対象とする場合が多いことから，今後アンカー体 の有効長と有効長比拈よび限界塑性変位量率（図-15) について多くのデー夕を収集することで，限界塑性変位 量率を利用したアンカー体の健全度評価が可能になるも のと考えられる。

\section{5. 既設アンカー体の健全度評価基準の提案}

以上のことから，既設アンカー体の健全度評価の具体 的な方法および留意点について提案する。

表一 4 アンカー体径と最大有効長の関係

Table. 4 Relation between diameter of anchor body and maximum effective length

\begin{tabular}{|c|c|c|c|c|}
\hline 実験 & $\begin{array}{c}\text { アンカー } \\
\text { 形式 }\end{array}$ & $\begin{array}{l}\text { アンカー体 } \\
\text { 径d }(\mathrm{cm})\end{array}$ & $\begin{array}{l}\text { 最大有効長 } \\
L_{E \max }(\mathrm{cm})\end{array}$ & $\begin{array}{l}\text { 有効長比 } \\
L_{\text {Emax }} / d\end{array}$ \\
\hline \multirow{2}{*}{ 模型 } & 引張型 & \multirow{2}{*}{1.3} & 30 & 23 \\
\hline & 圧縮型 & & 30 & 23 \\
\hline \multirow{2}{*}{ 現場 } & 引張型 & \multirow{2}{*}{11.5} & 250 & 22 \\
\hline & 圧縮型 & & 300 & 26 \\
\hline
\end{tabular}

表一 5 現場引抜き試験による塑性変位量率（引張型）

Table. 5 Plasticity deformation rate by site pull-out test (tention type)

\begin{tabular}{|c|c|c|c|c|c|c|c|c|}
\hline 地 質 & $\begin{array}{l}\text { 強度 } \\
\mathrm{MPa}\end{array}$ & $\begin{array}{l}\text { 自由 } \\
\text { 長 } \\
\mathrm{m}\end{array}$ & $\begin{array}{c}\text { アン } \\
\text { カー } \\
\text { 体径 } \\
\mathrm{cm}\end{array}$ & $\begin{array}{c}\text { アン } \\
\text { カー } \\
\text { 体長 } \\
\mathrm{cm}\end{array}$ & $\begin{array}{l}\text { 有効 } \\
\text { 長 } \\
L_{E} \\
\mathrm{~cm}\end{array}$ & $\begin{array}{c}\text { 引抜 } \\
\text { き } \\
\text { 荷重 } \\
\mathrm{kN}\end{array}$ & $\begin{array}{r}\text { 限界 } \\
\text { 塑性 } \\
\text { 変位 } \\
\mathrm{cm}\end{array}$ & $\begin{array}{c}r \\
\left(\delta / L_{E}\right) \\
\%\end{array}$ \\
\hline 砂 & 0.6 & 8.0 & 11.5 & 250 & 250 & 360 & 6.00 & 2.4 \\
\hline $\begin{array}{c}\text { 風化安 } \\
\text { 山岩 }\end{array}$ & 0.8 & 21.0 & 11.5 & 200 & 200 & 520 & 1.60 & 0.8 \\
\hline $\begin{array}{l}\text { 風化安 } \\
\text { 山岩 }\end{array}$ & 1.3 & 21.0 & 11.5 & 110 & 100 & 350 & 1.65 & 1.7 \\
\hline 泥 岩 & 2.0 & 5.0 & 11.5 & 350 & 253 & 700 & 2.10 & 0.8 \\
\hline $\begin{array}{c}\text { 風化凝 } \\
\text { 扊岩 }\end{array}$ & 3.8 & 1.1 & 11.5 & 500 & 253 & 820 & 0.98 & 0.4 \\
\hline 砂 岩 & 6.0 & 10.0 & 13.5 & 300 & 297 & 904 & 1.98 & 0.7 \\
\hline
\end{tabular}




\section{1 現地作業}

既設アンカーの塑性変位量は作業の効率化とアンカー 体の塑性変位を助長しないようにするため, リフトオフ 荷重から設計荷重にかけての 1 サイクル試験で行う。ま た地すべり防止施設等を点検することで，安定が維持さ れているか否かの確認をおこない，健全度評価を総合的 かつ適正に行うための基礎資料とする。

\section{2 健全度評価手順と評価基準}

表－ 6 はリフトオフ荷重（現状荷重）による健全度評 価基準であり，現状荷重が設計荷重以上の場合は過小設 計の疑いがある。設計荷重を保持できない場合は引抜け 状態であり，これらについては別途調査が必要である。

現状荷重が設計荷重以下であるが，再緊張により設計 荷重を保持できる場合は以下の手順で健全度評価を行う。

設計荷重等の管理資料がある場合は, 表 -7 より有効 長と限界塑性変位量を求め, 塑性変位量の累積值との比 較で現状を評価する。考え方として，アンカー体が健全

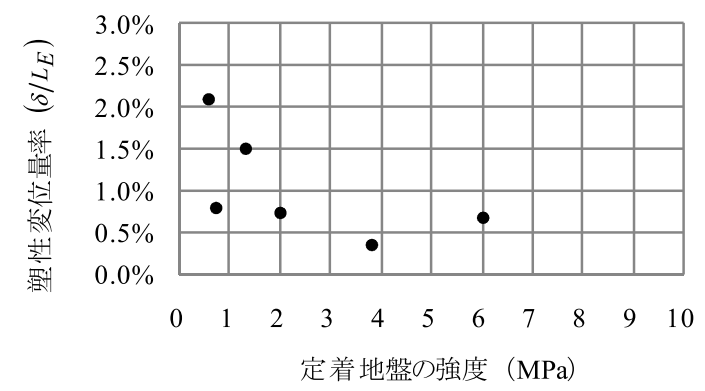

図一15 地盤強度一塑性変位量率 (引張型)

Fig. 15 Ground strength-plasticity deformation rate (tension type)

表ー6 リフトオフ試験で確認された現状荷重に基づくアン カー体の健全度評価と対策

Table. 6 Soundness diagnosis and measures of anchor body by the lift off load

\begin{tabular}{|c|c|c|c|}
\hline $\begin{array}{l}P_{P} \text { と } P_{1} \\
\text { の対比 }\end{array}$ & $\begin{array}{l}P_{1} \text { と } P_{0} \\
\text { の対比 }\end{array}$ & 評価内容 & 対 \\
\hline$P_{1}>P_{P}$ & \multirow[t]{2}{*}{$P_{1}>P_{0}$} & 過小設計 & $\begin{array}{l}\text { 抑止対象に新たな } \\
\text { 変状がある場合は } \\
\text { 早急に補強等の対 } \\
\text { 策が必要 }\end{array}$ \\
\hline \multirow[b]{3}{*}{$\begin{array}{c}P_{1} \leqq P_{P} \\
\quad\left(P_{P} \text { の保 }\right. \\
\text { 持は可能 })\end{array}$} & & $\begin{array}{l}\text { 抑止対象が変位 } \\
\text { した可能性有り }\end{array}$ & $\begin{array}{l}\text { 要注意として監視 } \\
\text { が必要 }\end{array}$ \\
\hline & $P_{1}=P_{0}$ & 問題なし & 不要 \\
\hline & $\begin{array}{c}P_{1} \leqq P_{0} \\
\quad\left(P_{1} \text { の保 }\right. \\
\text { 持は可能 })\end{array}$ & $\begin{array}{l}\text { 受圧板の沈下か } \\
\text { アンカー体のク } \\
\text { リープが懸念さ } \\
\text { れる他, テンド } \\
\text { ンのリラクゼー } \\
\text { ションなどが考 } \\
\text { えられる }\end{array}$ & $\begin{array}{l}\text { 締め付け機能を評 } \\
\text { 価した設計では, } \\
\text { 構造物の変状等に } \\
\text { よる現状の安定状 } \\
\text { 態を総合的に勘案 } \\
\text { た上で再緊張等 } \\
\text { の対策を検討する }\end{array}$ \\
\hline $\begin{array}{l}P_{1}<P_{P} \\
\left(\mathrm{P}_{\mathrm{P}} \text { の保持 }\right. \\
\text { も不可 })\end{array}$ & $\begin{array}{c}P_{1}<P_{0} \\
\quad\left(P_{0} \text { の保 }\right. \\
\text { 持も不可 })\end{array}$ & 引抜け状態 & $\begin{array}{c}\text { 補強等の対策が } \\
\text { 必要 }\end{array}$ \\
\hline
\end{tabular}

$\left(P_{P}\right.$ : 設計荷重, $P_{1}$ : 現状荷重, $P_{0}$ : 初期緊張荷重 $)$
であれば塑性変位は生じない。アンカー体が劣化すれば 塑性変位が進行し，荷重低下をきたす。その段階でリフ トオフ試験（1 サイクル試験）を実施すれば，荷重低下 量に相当する塑性変位を確認することができる。これら の荷重低下状況や塑性変位の経年変化を追跡することで, アンカー体の劣化進行状況や限界值に達する期間の推定 が可能である。なお同表に示す限界塑性変位量率 $r$ につ いては今後多くのデー夕収集による補填が必要である。

管理資料がない場合は，荷重一塑性変位量曲線の形態 （図－10，13）および累積塑性変位量の経年変化に基つ き評価する。すなわち，リフトオフ試験による変位量曲 線や経年的累積塑性変位量に増大傾向がない場合は健全 であるが，漸増傾向にあれば要注意となる。

さらに管理資料の有無に関わらず，リフトオフ試験等 の観測日までに生ずる塑性変位量は不明である。これに 対しては前回観測日からの荷重低下速度を指標にするか, 定期観測を行うなどの対応策が考えられる。

\section{6. 健全度評価における留意点}

\section{1 アンカーカが定着部に有効に伝わっていない可 能性について}

表 -8 は基本調査試験および工事での多サイクル試験 において, 緊張時の自由長とテンドンの弾性変位量から 求められる自由長（以下計算自由長とする）を比較した ものであり，これを図化したものを図－16に示す。

同図より全体として,1本引きのものは理論通りの伸び 変位を示すが, 複数のより線からなるテンドンは理論伸 び量を下廻り，特に自由長が $15 \mathrm{~m}$ 越えると大きく低下 する傾向にある。さらにこのテンドンが 1 本引きか複数 であるかの違いは，自由長部のグラウトの有無よりも影 響が大きい傾向にある。理論通りの伸び変位がないこと は設計アンカーカが定着部に有効に伝達されていないこ とを示唆するものであり, 今後検討すべき課題である。

\section{2 設計荷重が不明な場合の対応}

設計荷重が不明な場合は, アンカー体の塑性変形の進 行をできるだけ抑制するため，使用されているテンドン

\section{表ー 7 アンカー体の形式と限界塑性変位量の関係}

Table. 7 Relation between anchor type and critical plastic deformation 's amount of anchor body

\begin{tabular}{|c|c|c|}
\hline 工 法 & 引張型 & 圧縮型 \\
\hline $\begin{array}{l}\text { 引抜けるまで } \\
\text { の荷重一塑性 } \\
\text { 変位量曲線の } \\
\text { 形態 }\end{array}$ & $\begin{array}{l}\text { 荷重初期段階より漸増し, } \\
\text { 引抜け前に急増 }\end{array}$ & $\begin{array}{l}\text { 引抜け直前段階 } \\
\text { に急増 }\end{array}$ \\
\hline $\begin{array}{c}\text { 最大有効長 } \\
L_{E \max }\end{array}$ & アンカー孔径の約 22 倍 & $\begin{array}{c}\text { アンカー孔径の } \\
\text { 約 } 26 \text { 倍 }\end{array}$ \\
\hline \multirow{2}{*}{$\begin{array}{l}\text { 限界塑性 } \\
\text { 変位量率 } r\end{array}$} & $q_{u} \fallingdotseq 1 \mathrm{MPa} \sigma$ 時 $r=1 \sim 2 \%$ & $0.1 \sim 0.2 \%$ \\
\hline & $q_{u}=2 \sim 6 \mathrm{MPa}$ の時 $r=0.5 \%$ & $\left(q_{u}=2 \sim 4 \mathrm{MPa}\right)$ \\
\hline $\begin{array}{l}\text { 限界塑性 } \\
\text { 変位量※) }\end{array}$ & $L \times r$ & $L \times r$ \\
\hline
\end{tabular}




\section{表ー8引張試験時のテンドンの弾性変位量から求めた計算 自由長と緊張時の自由長との差}

Table. 8 Relation between actual free length and calculation's free length by tensile test

\begin{tabular}{|c|c|c|c|c|c|c|c|c|}
\hline No & $\begin{array}{l}\text { アン } \\
\text { カー }\end{array}$ & $\begin{array}{l}\text { 最大 } \\
\text { 荷重 }\end{array}$ & $\begin{array}{c}\text { 弾性 } \\
\text { 変位 } \\
\text { 量 }\end{array}$ & $\begin{array}{l}\text { テン } \\
\text { ドン }\end{array}$ & $\begin{array}{l}\text { 自由 } \\
\text { 長 }\end{array}$ & $\begin{array}{l}\text { 計算 } \\
\text { 自由 } \\
\text { 長 }\end{array}$ & $L{ }_{1} / L$ & $\begin{array}{l}\text { 自由 } \\
\text { 長部 } \\
\text { グラ }\end{array}$ \\
\hline & & $\mathrm{kN}$ & $\mathrm{mm}$ & $\mathrm{mm} \times$ 本 & $L \mathrm{~m}$ & $L_{1} \mathrm{~m}$ & $\%$ & ウト \\
\hline a1 & 圧縮 & 500 & 71.3 & \multirow{4}{*}{$12.7 \times 4$} & 13.2 & 11.9 & 90 & \multirow{5}{*}{ なし } \\
\hline a2 & 引張 & 400 & 53.4 & & 11.0 & 10.5 & 96 & \\
\hline a3 & 圧縮 & 450 & 90.4 & & 22.1 & 17.0 & 77 & \\
\hline $\mathrm{a} 4$ & 引張 & 360 & 78.7 & & 20.3 & 17.4 & 86 & \\
\hline $\mathrm{b}$ & 圧縮 & 390 & 93.6 & $21.8 \times 1$ & 15.5 & 16.2 & 105 & \\
\hline $\mathrm{c}$ & \multirow{5}{*}{ 圧縮 } & 910 & 104.7 & $12.7 \times 7$ & 26.7 & 16.9 & 63 & \multirow{5}{*}{ 有り } \\
\hline $\mathrm{d} 1$ & & 297 & 65.1 & \multirow{4}{*}{$17.8 \times 1$} & 10.1 & 9.7 & 96 & \\
\hline $\mathrm{d} 2$ & & 297 & 77.5 & & 12.0 & 11.6 & 97 & \\
\hline $\mathrm{d} 3$ & & 297 & 54.5 & & 7.8 & 8.1 & 104 & \\
\hline $\mathrm{d} 4$ & & 297 & 62.1 & & 8.8 & 9.3 & 105 & \\
\hline
\end{tabular}

構成の 1 ランク下における最大許容荷重を用いることを 提案する。

\section{7. まとめ}

アンカー体（引張型，圧縮型）の健全度について，そ の支持機構や塑性変形を踏まえた評価手法の検討結果を 以下に示す。

1）アンカー体周辺地盤の応力状態より，引張型では荷 重増とともに引張り側から徐々にアンカー体あるい はテンドンが変位し，周辺地盤に幅広く荷重分散を もたらすことが確認された。この荷重分散が効果的 に働く区間が有効長をなし，主に摩擦を主体とした 引抜き抵抗を発揮するものと考えられる。

2 ）圧縮型ではアンカー体の引抜き直前状態において, 拘束具から引張り側方向に紡錘状の圧縮帯の形成が 確認されたことから，主にアンカー体および周辺地 盤の支圧強度による引抜き抵抗を発揮するものと考 えられる。

3 ）アンカー孔径に対するアンカー体の有効長比は，模 型地盤（ $q_{u}=2 \sim 3.5 \mathrm{MPa} ）$ を用いた引抜き試験で は，引張型および圧縮型とも23倍であった。現場で の引抜き試験（ $\left.q_{u}=3.8 \mathrm{MPa}\right)$ では引張型で 22 倍, 圧縮型で26倍であった。

4 ）引抜き試験時の荷重－変位量曲線におけるアンカー 体の引抜き形態は，引張型では荷重初期段階から放 物線状の漸増曲線を描くが，圧縮型では引抜き直前 段階で急増する形態を示す。いずれも引抜ける前に は一定の塑性変位量があり，その限界值（限界塑性 変位量）は，ともに塑性変位量が急増する時点を目 安にすることができる。従って既設アンカーの設計 資料等がない場合は，定期的に 1 サイクル試験によ

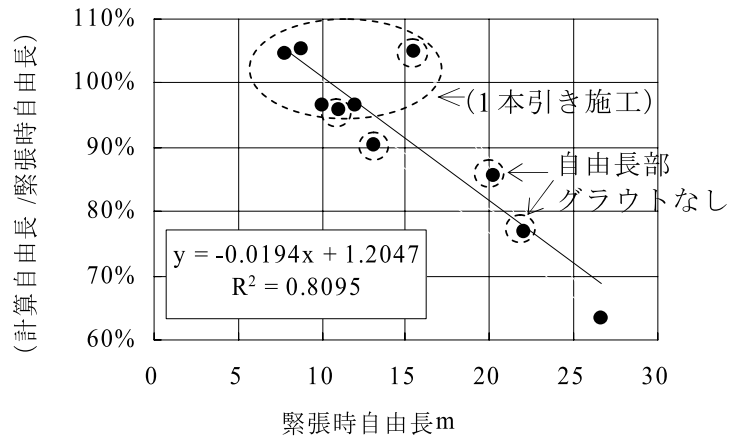

図ー16 自由長の長さが引張り試験時の計算自由長に与える 影響

Fig. 16 Influence that actual free length gives calculation's free length

る塑性変位量曲線の形態や塑性変位量の経年変化を 管理することでアンカー体のおよその健全度評価が 可能である。

5）上記 3 ）に示した有効長比が妥当であるとした場合， アンカー体が引抜けるときの限界塑性変位量率（現 場実験）は引張型では $q_{u} \fallingdotseq 1 \mathrm{MPa} て ゙ ~ 1 \sim 2 \%, q_{u}=$ $2 \sim 6 \mathrm{MP}$ 約 $0.5 \%$, 圧縮型では $q_{u}=3.8 \mathrm{MPa}$ $0.1 \%$ あった。引張型の方が大きくなるのはアン カー体の支持機構の違いを反映するものであり，工 事施工段階からのアンカー体の塑性変位量を管理す れば，現状の健全度評価や供用可能期間の推定など が可能となる。

6 ）管理上の留意点として，塑性変位量を管理する確認 試験はアンカー体の塑性変位を助長させないために, 既設アンカーのリフトオフ荷重から設計荷重におけ る 1 サイクル試験とすることが適当である。また設 計荷重が不明な場合はテンドン構成の 1 ランク下に おける最大許容荷重を管理值とすべきである。

7 ）問題点として，複数のより線からなるテンドンの自 由長が $15 \mathrm{~m}$ 越えるような場合には，確認試験時の テンドンの伸び量が理論伸び量を下迴り，定着部に 設計アンカーカが適正に伝達していない可能性があ る。抑止対象となる地すべりの安全率にも関わるこ とから，これに対する解決策が必要である。

今後アンカー体の有効長や限界塑性変位量に関して多 様な地盤強度におけるデー夕を集積する必要があるほか, メンテナンス作業を的確にする上で施工管理資料の整備 など管理体制の構築も急務と考える。

\section{参考文献}

1) (独) 土木研究所，(社) 日本アンカー協会（2008）：グラウンド アンカー維持管理マニュアル，p. $72 ， p .80$.

（原稿受付2010年 6 月 9 日，原稿受理2010年 6 月 22 日） 